\title{
Network research project as a model of group mentoring in work with gifted children
}

\author{
Tat'yana Sergeyeva ${ }^{*}$, Dmitriy Yermakov ${ }^{2}$, Daud Mamiy $^{3}$, and Mariya Shabanova ${ }^{4}$ \\ ${ }^{1}$ Moscow City University, Directorate of Educational Programs, Moscow, Russia \\ ${ }^{2}$ Peoples' Friendship University of Russia (RUDN University), Department of Psychology and \\ Pedagogy, Moscow, Russia \\ ${ }^{3}$ Adyghe State University, Maykop, Russia \\ ${ }^{4}$ Moscow Center for Education Quality, Department of Training Specialists in Educational Areas, \\ Moscow, Russia
}

\begin{abstract}
The article is devoted to a model of group mentoring in work with gifted children, which is considered to be a way of transferring knowledge, skills, and abilities from a more experienced and knowledgeable specialist to a young person, providing young people with support in socialization and growing up. The article presents many years of experience of using network research projects organized by the Association of Teachers Working with Gifted Children. The article identifies the conditions necessary for the organization of a network research project. The functions of teachers participating in projects as tutors are described. The formats of network project organization are indicated: game, business project, research, quest, etc. The authors consider examples of some network projects in the form of an organizational activity game and business project. The effectiveness of network research projects as a form of group mentoring has been identified based on expert assessments of skills development changes among gifted students. Skills, on the development of which the work in network projects focuses, are information skills (the ability to search for information, master modern information and communications technology, etc.), communicative skills (the ability to interact productively), teambuilding skills (the ability to work in groups with both permanent and changing members, etc.), and skills of presenting scientific ideas (the ability to visualize, describe, and present projects).
\end{abstract}

Keywords: giftedness, mentors, project design, networking.

\section{Introduction}

The fundamental changes that characterize the modern era require the following from the human community: mobility, readiness for change and shift of focus, innovative thinking, and the ability to solve non-standard problems.

According to the culturological concept by A.J. Toynbee, civilization becomes viable if it manages to respond to existing challenges. "The history of any civilization is a series of challenge-and-response interactions" [1]. A civilized society is characterized by individuals

* Corresponding author: cirr1@mail.ru 
who are divided into two groups. The minority of them are creative and the majority are inert. The creative pioneers help society to overcome stagnation and encourage the development of civilization.

Today's gifted children are future creative pioneers who can find solutions to the challenges of civilization, but only if there are opportunities for their development and selfrealization. This requires redefining the role of education as the main social value and a factor determining the quality of human potential.

According to the modern understanding of education, it is a process that shapes the knowledge, temper, and behavior of young people. At the same time, it is emphasized that this is a continuous and life-long process of growth and development. In ancient times, the main goal of education was to gain as much knowledge as possible. In turn, modern education is aimed at developing individuality and achieving social efficiency and vibrancy. Education is considered to be a bipolar process, in which a person influences another to change the development of the latter.

The above-mentioned understanding of modern education encourages the emergence of new forms of interaction between students and teachers, which, among other things, include mentoring.

\section{Methods}

During the study, a model was developed of gifted children group mentoring in the form of network research projects.

The following methods were used: literature and educational practice review, theoretical modeling, project design, observation, expert assessment, etc.

In ancient times, mentoring was considered to be a form of adults teaching applied knowledge, necessary behavior, and instrumental skills to youth and the formation of their life values and positive attitudes [2].

The effectiveness of mentoring gifted children is presented in a wide range of studies [38]. In the biographies of famous people who managed to overcome huge obstacles to achievements, there is always a mentor, parent, teacher, friend, or relative who said "you can do this", encouraging them to overcome obstacles and achieve their goal.

According to Sandra Berger, one of the main advantages of mentoring a gifted student is the opportunity to communicate with a professional, who is ready to share personal knowledge, ideas, experience, and values. At the same time, the communication between a mentor and student contributes to their mutual enrichment and can provide both the mentor and student with inspiration and new ideas [9].

One of the commonly used models of mentoring is group mentoring when one mentor works with a group of gifted students. It is widespread in resource-limited situations.

\section{Results}

One of the forms of group mentoring is a network research project that brings together students, teachers, and scientists. The basis for a network research project is a current problem that is interesting to the participants. During the project work, the participants search for a solution to the problem through productive interaction using modern digital technology.

The creation of a network research project is possible only under the following conditions:

1. The presence of a group of professionals who put forward an idea. This refers to the formation of a community of professionals and gifted students, united not only by common interests in a particular area but also common ideas and values. The involvement of gifted children in the activities of such a community contributes not only to the development of 
their talent but also research behavior models and attitude to science, as well as the formation of scientific communication skills, etc.

2. The organization of free communication between the participants, which is carried out through the creation of micro and macro groups in various areas of activity. In the process of such communication, the idea is popularized and promoted more effectively.

3. The availability of resources for the interaction between project participants and modern information and communications technology, which allows them, on the one hand, to communicate productively and exchange content more effectively and, on the other hand, to become a source of new ideas.

4. The availability of a platform for presenting the results and outcomes of network research projects. It can be a competition, regular seminar, research conference, and other forms, within which the expert community evaluates projects, and gifted students acquire experience in the field of scientific communication.

One of the important outcomes of the involvement of gifted students in network research projects is the development of subjectivity, which can be considered their ability to selfdevelopment. Subjectivity, which, according to A.G. Asmolov, is one of the systemic characteristics of activity, reflects a person's self-awareness as a doer, transformer, and life creator; perception of events and actions is its highest form [10].

Network research projects are organized as part of the activities of the Association of Teachers Working with Gifted Children, which is a non-profit organization that unites teachers from different regions of Russia. The participants are leading specialists, scientists, teachers, and gifted students from different regions of Russia and different countries as well, who communicate using digital technology.

The platform for organizing network research projects is the international competition "Mathematics and Design", which has been held in Russia since 2006, organized by scientists and teachers from Russia and Bulgaria [11]. A wide range of nominations allows taking into account various interests of gifted students.

Network research projects have been included in the competition since 2016. In the past four years, more than 80 gifted children and 10 teachers took part in their development. Leading experts in the field of mathematics and methods of teaching mathematics from Russia and Bulgaria were involved in group mentoring.

The participants of each project were gifted students, teachers, and a leading specialist (scientist), who was a group mentor of the project. The mentor's functions consisted in putting forward the research problem, defining tasks, advising on the choice of research method and the justification of the results and conclusions, and presenting the outcomes.

Teachers, who participated in the project, provided tutoring support. Their functions included task distribution, organization of interaction between students, control of work performance, coordination of interaction between students and their group mentor, project preparation for a presentation at the competition, etc.

Work on network projects was carried out in various formats according to the age of students: game, business project, research, etc.

The network project "Geometric Scrabble in the Clouds", which was led by Professor Maria Valerievna Shabanova, Doctor of Education, was carried out in the form of an organizational activity game. During the project, it was necessary to compose and solve problems that develop the idea of the original geometric problem: to find the geometric location of points using the integrative geometric environment Geogebra.

The network project "Youth Business - Exploring Opportunities" was led by Larisa Valentinovna Vorkunova, $\mathrm{PhD}$ in Education. The project was aimed at developing business projects for young people using a mathematical model. The project participants were schoolchildren and college students from Russia and Bulgaria. 
By communicating with scientists during network research projects, students gain experience in conducting research activities in a meaningful and well-structured way. Therefore, not only distance communication using digital technology between students and mentors is important; it also involves as informal as possible face-to-face meetings, so that students feel free when discussing a problem and ways to solve it $[12,13]$. During face-toface meetings, not only the development of project participants in a particular area takes place, but also the formation of their attitude towards research activities, the development of an algorithm for their implementation, taking into account their preferences and strategies, as well as the reflection on this activity. Such a meeting is the full-time defense of projects, which takes place from May 1 to May 5 at the international competition "Mathematics and Design".

Another aspect that develops productively during the organization of network projects is scientific communication, which becomes more and more important in the context of involving students in project and research activities. Scientific communication, which is a combination of various types of professional communication in the field of science, is considered to be one of the key mechanisms of its development, professional interaction, and examination of research results $[14,15]$.

The interaction between scientists and schoolchildren who work together on projects and research allows future researchers to gain experience in an accessible and interesting way and talk about their inventions and contributes to the formation of skills necessary for the promotion of scientific ideas.

\section{Conclusion}

The effectiveness of the influence of group mentoring in the form of network research projects was identified based on teachers' expert assessments. Skills, on the development of which the work in network projects focuses, were identified: information skills (the ability to search for information, master modern information and communications technology, etc.); communicative skills (the ability to interact productively), team-building skills (the ability to work in groups with both permanent and changing members, etc.), skills of presentation of scientific ideas (the ability to visualize, describe, and present projects).

Teachers, who participated in projects, noted a significant increase in the level of the above-mentioned skills, as well as in the motivation and cognitive activity of students. Besides, some students wanted to continue their work at the next stages of education.

Network research projects encourage students to independently search and penetrate the process of knowledge evolution and encourage further critical thinking and analysis. Communication with mentoring scientists allows students to gain not only knowledge in a particular area but also priceless scientific experience of formulating and solving research problems, their presentation and popularization.

\section{Acknowledgments}

The reported study was funded by the Russian Foundation for Basic Research (RFBR) according to the research project No. 20-013-00730.

\section{References}

1. A.J. Toynbee, A Study of History, Abridienent by D.C. Somervell (Oxford University Press, London, New York, 1988)

2. B.M. Bim-Bad, Pedagogicheskii entsiklopedicheskii slovar [Pedagogical encyclopedic 
dictionary], (Bolshaya rossiiskaya entsiklopediya, Moscow, 2002)

3. D. Lakind, M. Atkins, J.M. Eddy, Children and youth services review, 53, 52-60 (2015). https://doi.org/10.1016/j.childyouth.2015.03.007

4. A.B. McBride, J. Campbell, N.F. Woods, S.M. Manson, Nursing outlook, 65(3), 305314 (2017)

5. N.Kh. Agakhanov, T.F. Sergeeva, O.K. Podlipskii, Teoriya i praktika raboty s matematicheski odarennymi detmi [Theory and practice of work with mathematically gifted children] (Ileksa, Moscow, 2018)

6. S.I. Pfeiffer, APA Handbook of giftedness and talent (American Psychological Association, Washington, 2017)

7. E.A. Dudina, Vestnik Novosibirskogo gosudarstvennogo pedagogicheskogo universiteta, 8(6), 41-57 (2018). https://doi.org/ 10.15293/2226-3365.1806.03

8. M.V. Ermolaeva, A.S. Ognev, E.V. Likhacheva, Sovremennye problemy nauki i obrazovaniya, 2, 684 (2015)

9. S.L. Berger, Mentor Relationships and Gifted Learners (ERIC Clearinghouse on Handicapped and Gifted Children, Reston VA, 1990). Accessed on: December 16, 2020. [Online]. Available: https://www.vtaide.com/png/ERIC/gifted-mentoring.htm

10. A.G. Asmolov, Psikhologiya lichnosti: Printsipy obshchepsikhologicheskogo analiza [Personality psychology: general psychological analysis principles] (Smysl, Moscow, 2001)

11. A.I. Salov, T.F. Sergeyeva, Matematika v shkole, 6, 77-80 (2016)

12. M. Scott, Otkryvaya organizatsii budushchego [Reinventing Organizations] (MIF, Moscow, 2019)

13. S.V. Zenkina, E.K. Gerasimova, O.P. Pankratova, Setevaya proektno-issledovatelskaya deyatelnost obuchayushchikhsya [Network design and research activities of students] (Urait, Moscow, 2020)

14. O.V. Vydrin, Vestnik Chelyabinskogo gosudarstvennogo universiteta, 42(180), 112 117 (2009)

15. E.G. Skibitskii, E.G. Kitova, Nauchnaya kommunikatsiya [Scientific communication] (Urait, Moscow, 2018) 